\title{
СРАВНИТЕЛЬНОЕ ИССЛЕДОВАНИЕ МИКРОБИОТЫ ЭЯКУЛЯТА МЕТОДОМ КОЛИЧЕСТВЕННОЙ ПЦР И КУЛЬТУРАЛЬНЫМ МЕТОДОМ
}

\author{
Е. С. Ворошилина ${ }^{1,2}$ У, Д. Л. Зорников ${ }^{1}$, Е. А. Паначева ${ }^{1,2}$
}

1 Уральский государственный медицинский университет, Екатеринбург, Россия

${ }^{2}$ Медицинский центр «Гармония», Екатеринбург, Россия

Одной из причин мужского бесплодия могут быть воспалительные заболевания урогенитального тракта, развитие которых в ряде случаев ассоциировано с условно-патогенными микроорганизмами (УПМ). В связи с этим актуальна проблема внедрения современных методов выявления и идентификации УПМ в урогенитальном тракте. Целью работы было провести сравнительный анализ результатов исследования микробиоты эякулята мужчин репродуктивного возраста с помощью количественной полимеразной цепной реакции (ПЦР) (тест Андрофлор) и культурального метода. Исследовали 86 образцов эякулята, собранных у мужчин в возрасте 18-57 лет после соблюдения полового воздержания в течение 3-5 суток. При культуральном исследовании в 50\% образцов наблюдали рост грамположительных факультативно анаэробных бактерий в количестве менее 103 КОЕ/мл; в 16,3\% образцов - роста бактерий отмечено не было. При использовании ПЦР в реальном времени (ПЦР-РВ) в каждом образце выявляли 8-15 групп микроорганизмов (в том числе определяли преобладающую) в количестве 10²-106 ГЭ/мл. Во всех 86 образцах были обнаружены облигатные анаэробы, которые не культивируются in vitro. Преобладающие группы микроорганизмов, определяемые в ПЦР-РВ, были выявлены культуральным методом только в 24,4\% случаев.

Ключевые слова: микробиота эякулята, ПЦР-РВ, культуральный метод

Благодарности: авторы благодарят директора Медицинского центра «Гармония» В. Н. Хаютина за предоставленную возможность проведения исследования на базе лабораторного отделения клиники.

Информация о вкладе авторов: Е. С. Ворошилина - организация исследования, выполнение ПцР-РВ, анализ данных, написание статьи; Д. Л. Зорников - анализ данных, статистическая обработка, написание статьи; Е. А. Паначева - обзор литературы, сбор клинических данных, статистический анализ, написание статьи.

Соблюдение этических стандартов: исследование одобрено этическим комитетом при ФГБОУ ВО УГМУ МЗ РФ (протокол № 4 от 18 октября 2017 г.). Все пациенты подписали информированное письменное согласие на участие в исследовании.

$\triangle$ Для корреспонденции: Екатерина Сергеевна Ворошилина

ул. Фурманова, 30, г. Екатеринбург, 620142; voroshilina@gmail.com

Статья получена: 11.02.2019 Статья принята к печати: 28.02.2019 Опубликована онлайн: 11.03.2019

DOI: $10.24075 /$ vrgmu.2019.009

\section{EVALUATION OF THE EJACULATE MICROBIOTA BY REAL-TIME PCR AND CULTURE-BASED TECHNIQUE}

Voroshilina ES $1,2 \otimes$, Zornikov DL ${ }^{1}$, Panacheva EA ${ }^{1,2}$

${ }^{1}$ Ural State Medical University of the Ministry of health, Yekaterinburg, Russia

${ }^{2}$ Medical Center "Garmonia", Yekaterinburg, Russia

\begin{abstract}
Among other things male sterility can be caused by inflammatory diseases of the urogenital tract, often associated with opportunistic microorganisms. Thus, it is necessary to implement modern methods for the detection and identification of opportunistic microorganisms in the urogenital tract. The aim of the work was to conduct comparative analysis of the ejaculate microbiota from men of the reproductive age and studied using quantitative polymerase chain reaction (PCR) and culture method. 86 samples of ejaculate collected from men aged 18-57 years after observing sexual abstinence for 3-5 days were examined. With culture study in $50 \%$ of samples we observed growth of gram positive facultative anaerobic bacteria in the amount less than $10^{3} \mathrm{CFU} / \mathrm{ml}$; in $16.3 \%$ of samples - the growth of bacteria was not observed. With real-time PCR in each sample 8-15 groups of microorganisms were detected (including the prevailing groups) in the amount of $10^{2}-10^{6} \mathrm{GE} / \mathrm{ml}$. In all 86 samples obligate anaerobes that cannot not be cultured in vitro were detected. The predominant groups of microorganisms, as determined by real-time PCR, were detected by the culture metod only in $24.4 \%$ of cases.
\end{abstract}

Keywords: ejaculate microbiota, real-time PCR, culture-based technique

Acknowledgments: the authors would like to thank V. N. Khayutin, director of Garmonia Medical Center, for allowing to conduct the study in the clinic's laboratory department.

Author contribution: Voroshilina ES — organization of the study, conducting tests, data analysis, article authoring; Zornikov DL — data analysis, statistical processing, article authoring; Panacheva EA — literature review, clinical data collection, statistical analysis, article authoring.

Compliance with ethical standards: the study was approved by the Ethics Committee of Ural State Medical University, Federal State Budget Educationa Institution of Higher Education under the Ministry of Health of the Russian Federation (Minutes № 4 of October 18, 2017). All patients signed the informed written consent to participation in the study.

$\triangle$ Correspondence should be addressed: Ekaterina S. Voroshilina

Furmanova 30, Yekaterinburg, 620142; voroshilina@gmail.com

Received: 11.02.2019 Accepted: 28.02.2019 Published online: 11.03.2019

DOI: 10.24075/brsmu.2019.009

Исследования последних лет изменили парадигму в отношении стерильности некоторых биотопов, в частности мочи и мочевого пузыря. В моче здоровых мужчин было установлено присутствие условно-патогенных микроорганизмов (УПМ) родов Lactobacillus, Sneathia, Veillonella, Corynebacterium, Prevotella, Streptococcus $и$ Ureaplasma [1]. Если результаты ранних исследований микробиоты урогенитального тракта (УГ) здоровых мужчин указывают на наличие микроорганизмов исключительно в уретре и венечной борозде [2, 3, 4], то в настоящее время бактерии обнаружены и в верхних отделах УП клинически здоровых мужчин, в частности в ткани простаты [5].

Микробиота эякулята состоит из комплекса микроорганизмов, происходящих из разных отделов 
УГТ. У здоровых мужчин она представлена главным образом микроорганизмами уретры, но при наличии патологического процесса дополнительно отмечаются микроорганизмы из верхних отделов УГТ [2].

Сведения о микробном составе эякулята при патологических состояниях (например, бесплодии и простатите) представляют огромный интерес для практической медицины. Недавно были выявлены различия в составе микробиоты эякулята у пациентов с простатитом и у здоровых мужчин: у последних отмечали большее количество Lactobacillus iners, тогда как у пациентов с простатитом - повышенное общее количество микроорганизмов, в том числе представителей филума Proteobacteria, а также большее видовое разнообразие микробиоты [6].

С инфекциями УГТ связано 6-10\% случаев мужского бесплодия [7]. Однако этиология большинства простатитов остается неясной, а отсутствие роста микроорганизмов при культуральном исследовании не позволяет подобрать адекватную схему терапии [8]. Обсуждается вопрос вклада отдельных УПМ в развитие воспалительных процессов УГТ. Отмечается, что при отсутствии облигатных патогенов такие УПМ как Escherichia coli, Klebsiella spp., Proteus spp., Enterococcus spp., Staphylococcus spp., Ureaplasma spp., Mycoplasma hominis могут являться триггером развития воспаления в этой области [7].

В последние десятилетия среди урогенитальных инфекций преобладают субклинические формы протекания заболеваний. В таких случаях диагноз устанавливают на основании лабораторных данных, отражающих интенсивность локального воспалительного ответа и состав микробиоты УГТ. Это обусловливает необходимость применения наиболее современных и информативных методов исследования, позволяющих получать точную инсормацию о микробном составе отделяемого УГТ.

На сегодняшний день для оценки микробиоты эякулята в клинической практике применяют несколько подходов. Наряду с культуральным исследованием в практику внедрен метод количественной ПЦР с детекцией результатов в режиме реального времени (ПЦР-РВ) - тест Андрофлор. Он позволяет проводить количественную оценку сложных микробных сообществ, в образовании которых принимают участие разнообразные микроорганизмы, в том числе трудно культивируемые и некультивируемые. Однако рекомендовать ПЦР-РВ в качестве полноценной замень культурального метода для исследования микробиоты эякулята затруднительно ввиду отсутствия качественно проведенных сравнительных исследований.

Целью работы было провести сравнительный анализ результатов исследования микробиоты эякулята с использованием культурального метода и ПЦР-РВ (тест Андрофлор).

\section{ПАЦИЕНТЫ И МЕТОДЫ}

В период с января по май 2018 г. были отобрань образцы эякулята 86 мужчин, обратившихся в Медицинский центр «Гармония» (г. Екатеринбург) для решения репродуктивных проблем. Возраст пациентов составил 18-57 лет (средний возраст $34 \pm 6,7$ лет). Критерии включения в исследование: соблюдение полового воздержания в течение 3-5 суток до исследования для исключения возможной контаминации материала транзиторной микрофлорой (Lactobacillus spp.) партнерши. Критерии исключения из исследования: обнаружение облигатных патогенов (Chlamydia trachomatis, Neisseria gonorrhoeae, Mycoplasma genitalium, Trichomonas vaginalis). Непосредственно перед сбором материала пациенту требовалось помочиться, полностью опорожняя мочевой пузырь. Сбор эякулята пациенты осуществляли путем мастурбации в стерильный контейнер объемом до 60 мл, избегая касания стенок и крышки контейнера руками. Транспортировку проб эякулята в лабораторию осуществляли в термоконтейнере в течение не более 4 ч с момента сбора образца. Культуральное исследование и ПЦР-РВ выполняли одновременно из одной пробы.

Культуральное исследование эякулята проводили в микробиологической лаборатории «Кволити Мед» (г. Екатеринбург). Для этого 1 мл эякулята разводили стерильным фризиологическим раствором (1: 1) и центрифугировали при 1500 об./мин в течение 15 мин. После удаления супернатанта по 10 мкл осадка высевали на 5 питательных сред (Bio-Rad; Франция): 5\%-й кровяной агар, обогащенный сывороткой и дрожжевым экстрактом; шоколадный агар, приготовленный на основе кровяного агара; хромогенный агар UriSelect4; агар Сабуро; маннит-солевой агар. Посевы инкубировали при $37^{\circ} \mathrm{C}$ в течение 24-48 ч в аэробных условиях и в атмосфере, содержащей 5\% $\mathrm{CO}_{2}$. Идентификацию полученных колоний микроорганизмов производили методом время-пролетной матричноассоциированной лазерной десорбционной ионизационной масс-спектрометрии (MALDI-TOF MS) на анализаторе Vitek MS (BioMerieux; Франция).

ПЦР-исследование проводили в лаборатории МЦ «Гармония» (г. Екатеринбург). Для проведения ПЦР-РВ 1 мл эякулята помещали в пробирку Эппендорф с 1 мл транспортной среды с муколитиком (ИнтерЛабСервис; Россия), встряхивали с помощью центрифуги «Фуга/ вортекс Микро-Спин FV-2400» (BioSan; Латвия) до полного перемешивания. Пробирку центрифугировали при 13000 об./мин в течение 10 мин. После удаления надосадочной жидкости 50 мкл осадка использовали для последующего выделения ДНК с помощью комплекта реагентов ПРОБА-ГС (ДНК-Технология; Россия) согласно инструкции производителя; амплификацию ДНК целевых групп УПМ проводили с помощью набора реагентов «Андросрлор (ДНК-Технология; Россия) в детектирующем амплификаторе ДТ-96 согласно инструкции производителя (ДНК-Технология; Россия) [9]. После реакции амплификации по показателю индикаторного цикла с помощью специального программного обеспечения (ДНК-Технология; Россия) проводили автоматический расчет количества общей бактериальной массы (ОБМ) и каждого из УПМ в представленном образце. Количество выявленных микроорганизмов выражали в геномэквивалентах на 1 мл (ГЭ/мл). Расчет доли отдельных видов и групп бактерий проводили относительно суммы всех выявленных в образце микроорганизмов. Спектр определяемых набором УПМ представлен следующими группами: грамположительные факультативно анаэробные микроорганизмы (Streptococcus spp. Staphylococcus spp., Corynebacterium spp.); грамотрицательные факультативно анаэробные микроорганизмы (Haemophilus spp., Pseudomonas aeruginosa / Ralstonia spp. / Burkholderia spp.); группа Enterobacteriaceae / Enterococcus spp.; облигатно анаэробные микроорганизмы (Gardnerella vaginalis, Eubacterium spp., Sneathia spp. / Leptotrichia spp. / Fusobacterium spp., Megasphaera spp. / Veillonella spp. / Dialister spp., Bacteroides spp. / Porphyromonas spp. / Prevotella spp., 
Anaerococcus spp., Peptostreptococcus spp., Atopobium cluster), микоплазмы (Mycoplasma hominis, Ureaplasma urealyticum, Ureaplasma parvum), транзиторная микробиота (Lactobacillus spp.), грибы рода Candida.

Статистическую обработку данных проводили с помощью пакета прикладных программ Microsoft Excel 2016 (Microsoft; США), пакета статистических программ WinPepi. Сравнительный анализ частоты выявления различных вариантов микробиоты культуральным методом и ПЦР-РВ проводили с помощью двустороннего критерия Фишера, различия считали достоверными при $p<0,05$.

\section{РЕЗУЛЬТАТЫ ИССЛЕДОВАНИЯ}

\section{Результаты культурального исследования эякулята}

При культуральном исследовании рост микроорганизмов обнаружили в 72 (83,7\%) из 86 образцов эякулята, идентифицировали 28 видов микроорганизмов. В 14 (16,3\%) образцах рост бактерий отсутствовал.

В 33 (38,4\%) образцах эякулята при культивировании выявили только один микроорганизм, идентифицировали 10 видов. В большинстве случаев это были представители нормальной микробиоты УГТ мужчин или кожи. В 21 (63,6\%) из 33 образцов микробиота была представлена одним из грамположительных факультативно анаэробных микроорганизмов: Staphylococcus spp. (S. epidermidis, S. haemolyticus, S. hominis); Streptococcus spp. (S. anginosus), Corynebacterium coyleae, Dermabacter hominis. B 8 (24,2\%) случаях обнаружили Enterococcus faecalis, в 4 (12,2\%) из 33 образцов выявили грамотрицательные факультативно анаэробные бактерии Klebsiella oxytoca, E. coli, Moraxella osloensis.

При выявлении монокультуры в образце эякулята количество бактерий в большинстве случаев $(28$ (84,8\%) из 33) было клинически малозначимым и составляло $10^{2}-10^{3}$ KOE/мл. В 6 (18,2\%) образцах количество выявленных бактерий составило $10^{4} \mathrm{KOE} / \mathrm{Mл,} \mathrm{и} \mathrm{только} \mathrm{в} \mathrm{одном}$ образце - $10^{6} \mathrm{KOE} / \mathrm{мл.}$

В 27 (31,4\%) из 86 образцов выявили по 2 вида микроорганизмов, идентифицировали 20 видов. Исключительно грамположительные фракультативно анаэробные бактерии выявили в 16 (59,3\%) из 27 образцов, характерными были сочетания S. mitis / S. oralis 8 случаев; C. glucuronolyticum / S. epidermidis и E. faecalis/ S. epidermidis - по 2 случая; E. faecalis / S. haemolyticus, S. capitis / S. haemolyticus, S. epidermidis / S. agalactiae, C. glucuronolyticum / E. faecalis - по одному случаю. В одном образце были выявлены только грамотрицательные микроорганизмы: Enterobacter hormaechei / Pseudomonas aeruginosa. В 5 (18,5\%) образцах одновременно присутствовали грамположительные и грамотрицательные факультативно анаэробные микроорганизмы: E. faecalis/ E. coli - в 2 случаях; Klebsiella pneumoniae / S. haemolyticus в 2 случаях и E. faecalis / K. oxytoca - в одном. В $2(7,4 \%)$ образцах эякулята выявили G. vaginalis, в одном случае в сочетании с Actinomyces neuii, в другом - с S. epidermidis. Еще в 2 (7,4\%) образцах выявили Lactobacillus spp. в сочетании с грамположительными кокками: L. iners / S. gallolyticus, L. crispatis / S. warneri.

При выявлении двух культур в образце количество выделенных бактерий в 17 (62,9\%) из 27 образцов составило $10^{2}-10^{3} \mathrm{KOE} / \mathrm{мл,} \mathrm{что} \mathrm{расценивают} \mathrm{как}$ клинически малозначимое [10]. В 9 (33,3\%) образцах количество одного из выявленных видов (E. faecalis,
K. oxytoca, G. vaginalis, S. agalactiae) составило $10^{4} \mathrm{KOE} / \mathrm{Mл.}$ Только в одном образце количество обоих выделенных видов (K. pneumoniae / S. haemolyticus) составило $10^{6} \mathrm{KOE} / \mathrm{Mл.}$

Одновременно 3 микроорганизма выделили в 9 (10,5\%) из 86 образцов эякулята, идентифицировали 12 видов микроорганизмов в различных сочетаниях. В 4 (44,4\%) из 9 случаев микробиота была представлена исключительно грамположительными факультативно анаэробными бактериями из числа представителей нормальной микробиоты УГ: C. glucuronolyticum, S. mitis/ S. oralis, S. hominis. B 2 (22,2\%) образцах были выявлены сочетания C. glucuronolyticum / G. vaginalis / S. anginosus. В 3 случаях выявили сочетание грамположительных и грамотрицательных бактерий: S. agalactiae / E. coli/ C. glucuronolyticum; Corynebacterium amycolatum / E. hormaechei / E. faecalis и E. faecalis / E. coli / S. anginosus.

Количество выявленных бактерий при одновременном обнаружении трех видов в 3 из 9 случаев было клинически малозначимым (не более $10^{3} \mathrm{KOE} / \mathrm{Mл)}$ ), в остальных образцах как минимум один вид присутствовал в количестве $10^{4} \mathrm{KOE} / \mathrm{мл} \mathrm{и} \mathrm{более.} \mathrm{В} \mathrm{количестве} 10^{4} \mathrm{KOE} / \mathrm{Mл}$ и более определяли C. glucuronolyticum, E. hormaechei, E. faecalis, S. anginosus, G. vaginalis, S. agalactiae.

В 3 образцах при культуральном исследовании выявили по 4 и более микроорганизма одновременно. В одном случае это было сочетание C. gluconormum / E. faecalis / S. mitis / S. oralis / E. coli, где E. faecalis присутствовал в количестве $10^{4} \mathrm{KOE} / \mathrm{Mл.} \mathrm{В} \mathrm{двух} \mathrm{других} \mathrm{случаях} \mathrm{были}$ выявлены сочетания грамположительных представителей нормальной микробиоты в количестве не более $10^{3}$ KOЕ/мл, что в совокупности со спектром выявленных микроорганизмов позволяет предположить, что образцы могли быть контаминированы в процессе сбора эякулята.

\section{Результаты исследования эякулята методом ПЦР-РВ}

При использовании ПЦР-РВ микробиота была выявлена во всех 86 образцах эякулята. В каждом образце определяли 8-15 групп микроорганизмов, представленных в разных количествах - от $10^{2}$ до $10^{6}$ ГЭ/мл. Использование математического алгоритма для расчета доли каждого из микроорганизмов по отношению к ОБМ позволило определить в большинстве образцов численно преобладающую группу бактерий.

В $15(17,4 \%)$ из 86 образцов преобладали грамположительные факультативно анаэробные микроорганизмы, представители нормальной микробиоты УГТ мужчин - Streptococcus spp., Staphyloccus spp., Corynebacterium spp. В 27 (31,4\%) образцах - облигатные анаэробы, в 4 (4,7\%) - грамотрицательные факультативно анаэробные бактерии (P. aeruginosa / Ralstonia spp. / Burkholderia spp. и Haemophilus spp.). В 23 (26,7\%) образцах преобладали бактерии группы Enterobacteriaceae / Enterococcus spp.; в 7 (8,1\%) - транзиторная микробиота (Lactobacillus spp.); в 10 (11,6\%) пробах выявлены смешанные микробные сообщества, в которых выделить преобладающую группу не представлялось возможным. Последнее демонстрирует разнородность микробиоты, которую можно определить с помощью ПЦР-РВ в отличие от культурального метода.

Интерпретируя результаты оценки микрофлоры эякулята методом ПЦР-РВ, мы понимали, что рассматривать совокупность выявленных МО как микробное сообщество или микробиоценоз нельзя, так как бактерии попадают в эякулят из разных отделов УГ мужчины. Поэтому мы 
предлагаем дифференцировать варианты микробиоть эякулята по преобладающей группе микроорганизмов превышающей в процентном соотношении другие группы. По этому критерию были выделены 6 вариантов микробиоты эякулята, частота выявления различных вариантов была проанализирована с учетом ОБМ (табл. 1).

Анализ полученных данных позволил выявить несколько закономерностей. По мере увеличения ОБМ эякулята было отмечено статистически значимое снижение частоты выявления варианта III (с преобладанием группь Enterobacteriaceae spp. / Enterococcus spp.), в то время как достоверно возросла доля варианта IV (с преобладанием облигатных анаэробов). Отмечена тенденция к увеличению частоты выявления варианта V (с преобладанием транзиторной микробиоты, Lactobacillus spp.), что может быть обусловлено несоблюдением правил подготовки к сбору эякулята (воздержание от половых контактов в течение предшествующих 3-5 дней). Примечательно, что в образцах с низкой ОБМ чаще всего выявляли вариант III и вариант VI (смешанный, без преобладания определенной группы), по мере увеличения ОБМ структура микробиоты изменялась.

Вариант I (с преобладанием грамположительных факультативно анаэробных $\mathrm{MO}$ ) по результатам исследования методом ПЦР-РВ был выявлен только в 17,4\% случаев, в то время как при культуральном исследовании данная группа бактерий была выявлена в 50\% образцов.

\section{Сравнение результатов культурального метода и ПЦР-РВ}

Результаты культурального исследования были подтверждены методом ПЦР-РВ в 100\% случаев - при получении роста чистой культуры определенного микроорганизма были получены положительные сигналы в соответствующей группе в тесте Андросрлор. Однако при использовании ПЦР-РВ во всех образцах были обнаружены другие группы

Таблица 1. Варианты микробиоты эякулята по данным ПЦР-РВ ( $n=86)$ микроорганизмов, отсутствовавшие в посеве. Особо стоит отметить, что во всех образцах с помощью ПЦР-РВ были идентифицированы некультивируемые in vitro облигатные анаэробы.

При использовании ПЦР-РВ микрофлора была обнаружена во всех 14 «стерильных» пробах эякулята. В данных образцах чаще всего определяли вариант III (с преобладанием группы Enterobacteriaceae spp. / Enterococcus spp.) - 5 (35,7\%) из 14 проб и вариант I (с преобладанием грамположительных факультативно анаэробных МO) - 4 (28,5\%) из 14 проб. Варианту IV (с преобладанием облигатных анаэробов) выявленная микробиота соответствовала в 2 (14,3\%) пробах; на варианты II, V и VI — приходилось по одной пробе $(7,2 \%)$. ОБМ в этой группе проб была менее $10^{4}$ ГЭ/мл, что может отчасти объяснить отсутствие роста при культуральном исследовании.

Далее анализировали, насколько часто микроорганизм, выявленный в наибольшем количестве при культивировании, совпадал с преобладающей группой бактерий по данным ПЦР-РВ (табл. 2).

Результаты культурального исследования полностью соответствовали результатам ПЦР-РВ только в 21 (24,4\%) из 86 случаев. В этих образцах единственный выделенный вид микроорганизмов или численно превышающий количество других выделенных видов при культуральном исследовании относился К преобладающей группе микроорганизмов по данным ПЦР-РВ. В остальных случаях микробиота при культуральном исследовании либо отсутствовала (14 (16,8\%)), либо спектр выявленных или численно преобладающих микроорганизмов отличался.

Количество выявленных при ПЦР-РВ микроорганизмов совпадало с количеством, определенным при культуральном исследовании, в $41(47,7 \%)$ из 86 проб; превышало в 10-1000 раз - в 38 (44\%) образцах. В 7 (8,3\%) образцах количество выявленных микроорганизмов в ПЦР-РВ отличалось от количества, определенного методом посева, в меньшую сторону. Дискордантные результаты были

\begin{tabular}{|c|c|c|c|c|c|}
\hline $\begin{array}{l}\text { Вариант } \\
\text { микробиоты }\end{array}$ & $\begin{array}{c}\text { Преобладающая группа } \\
\text { микроорганизмов в микрофлоре эякулята }\end{array}$ & $\begin{array}{c}\mathrm{OБМ}<10^{3} \text { ГЭ/мл } \\
n(\%)\end{array}$ & $\begin{array}{c}\text { ОБМ } 10^{3}<10^{4} \text { ГЭ/мл } \\
n(\%)\end{array}$ & $\begin{array}{c}\text { ОБМ }>10^{4} \text { ГЭ/мл } \\
n(\%)\end{array}$ & $\begin{array}{l}\text { Достоверность } \\
\text { различий }\end{array}$ \\
\hline & & 1 & 2 & 3 & \\
\hline Вариант I & $\begin{array}{c}\text { Грамположительные факультативно } \\
\text { анаэробные микроорганизмы }\end{array}$ & $4(14,8)$ & $9(19,6)$ & $2(15,4)$ & $\begin{array}{l}p_{1-2}>0,05 \\
p_{1-3}>0,05 \\
p_{2-3}>0,05\end{array}$ \\
\hline Вариант II & $\begin{array}{c}\text { Грамотрицательные факультативно } \\
\text { анаэробные микроорганизмы }\end{array}$ & $2(7,4)$ & $2(4,4)$ & 0 & $\begin{array}{l}p_{1-2}>0,05 \\
p_{1-3}>0,05 \\
p_{2-3}>0,05\end{array}$ \\
\hline Вариант III & Энтеробактерии/энтерококки 1 & $12(44,4)$ & $8(17,4)$ & $3(23,1)$ & $\begin{array}{l}p_{1-2}<0,05 \\
p_{1-3}<0,05 \\
p_{2-3}>0,05\end{array}$ \\
\hline Вариант IV & Облигатные анаэробы & $2(7,4)$ & $19(41,3)$ & $6(46,2)$ & $\begin{array}{l}p_{1-2}<0,01 \\
p_{1-3}<0,01 \\
p_{2-3}>0,05\end{array}$ \\
\hline Вариант V & $\begin{array}{l}\text { Транзиторная микрофлора } \\
\text { (Lactobacillus spp.) }\end{array}$ & $1(3,7 \%)$ & $4(8,7)$ & $2(15,4)$ & $\begin{array}{l}p_{1-2}>0,05 \\
p_{1-3}>0,05 \\
p_{2-3}>0,05\end{array}$ \\
\hline \multirow[t]{2}{*}{ Вариант VI } & $\begin{array}{c}\text { Нет преобладающей группы } \\
\text { (смешанное микробное сообщество) }^{2}\end{array}$ & $6(22,2 \%)$ & $4(8,7)$ & 0 & $\begin{array}{l}p_{1-2}>0,05 \\
p_{1-3}>0,05 \\
p_{2-3}>0,05\end{array}$ \\
\hline & Всего в группе & 27 & 46 & 13 & \\
\hline
\end{tabular}

Примечание: ${ }^{1}$ - данный вариант был предложен в связи с особенностями компоновки теста Андрослор, в котором бактерии Enterobacteriaceae spp. $/$ Enterococcus spp. определяются в одной пробирке отдельно от прочих грамположительных и грамотрицательных факультативных анаэробов, но без учета принадлежности к конкретному семейству; ${ }^{2}$ - критерием для данного варианта микробиоты было присутствие нескольких групп микроорганизмов в равных или незначительно различающихся долях; ${ }^{3}$ - достоверность различий рассчитывали по двустороннему критерию Фишера. 
обусловлены выявлением в этих образцах при посеве следующих видов бактерий: S. agalactiae (в 2 пробах), S. anginosus (в 2 пробах), S. mitis / S. oralis, S. hominis, L. crispatus - по одному случаю. Дискордантные результаты связаны с тем, что ростовые свойства бактерий in vitro могут существенно различаться, а некоторые виды не переносят даже кратковременной транспортировки.

\section{ОБСУЖДЕНИЕ РЕЗУЛЬТАТОВ}

При культуральном исследовании образцов эякулята в большинстве случаев были выявлены грамположительные факультативно анаэробные МО, традиционно относимые к нормальной микробиоте УГТ мужчины. При этом в 43\% проб количество их было менее $10^{4} \mathrm{KOE} / \mathrm{Mл,} \mathrm{что}$ принято оценивать как клинически мало значимое [10]. Присутствие нескольких видов микроорганизмов из числа нормальной микробиоты в незначительном количестве может свидетельствовать о контаминации проб в процессе сбора.

Результаты культурального исследования были подтверждены методом ПЦР-РВ в 100\% случаев при получении роста чистой культуры определенного микроорганизма были получены положительные сигналы в соответствующей группе в тесте Андрофлор, в том числе во всех 14 «стерильных" пробах эякулята. Отсутствие роста in vitro большинства групп микроорганизмов, выявленных методом ПЦР-РВ, вполне объяснимо, так как многие из данных микроорганизмов являются трудно культивируемыми или некультивируемыми [11].

Основные различия между результатами культурального исследования и ПЦР-РВ касались преобладающей в микробиоте группы микроорганизмов. Полное соответствие по этому параметру было установлено только в 24,4\% случаев. Дискордантные результаты могут быть обусловлены двумя причинами: во-первых, различием ростовых свойств бактерий in vitro, во-вторых, гибелью некоторых видов при транспортировке. Кроме того, облигатно анаэробные микроорганизмы, присутствующие в эякуляте, не могут быть выявлены при рутинном культуральном исследовании, что искажает представления о микробиоте в целом.

Количество выявленных микроорганизмов в 1 мл эякулята различалось в 52,3\% образцов. В 44\% образцов ОБМ, определяемая методом ПЦР-РВ, была выше в 10-1000 раз по сравнению с культуральным методом. В 7 (8,3\%) образцах данный показатель был выше при культуральном исследовании. При этом мы понимаем, что прямое сравнение количеств микроорганизмов, выявленных в эякуляте методом ПЦР-РВ и культуральным методом, не вполне корректно. Эякулят значительно отличается по вязкости и гомогенности, что может приводить к неравномерному распределению микробных клеток в биоматериале. Стоит также отметить, что перед проведением ПЦР-РВ мы дополнительно обрабатывали эякулят средой с муколитиком, что снижало вязкость образца и, возможно, обеспечивало более равномерное распределение микроорганизмов в объеме исследуемого материала.

Полученные в ходе настоящего исследования данные позволяют рекомендовать метод ПЦР-РВ (тест Андрофлор) как альтернативу культуральному исследованию для комплексной оценки микробиоты эякулята.

\section{ВЫВОДЫ}

Параллельное исследование эякулята посредством ПЦР-РВ и культурального метода позволило оценить преимущества ПЦР-РВ (теста Андрофллор) для комплексной оценки микробиоты данного биологического материала. Использование только культурального метода для оценки микробиоты эякулята позволяло выявить лишь часть присутствующих в образце микроорганизмов, при этом каждый 6-й образец был «стерильным». Применение ПЦР-РВ позволило идентифицировать от 8 до 15 групп микроорганизмов в количестве 10²-106 ГЭ/мл во всех исследованных пробах эякулята, при этом в большинстве проб преобладала одна из групп микроорганизмов. Во всех 86 образцах, кроме вида,

Таблица 2. Сравнение преобладающих групп микроорганизмов по результатам культурального исследования и ПЦР-РВ ( $n=86)$

\begin{tabular}{|c|c|c|c|c|c|c|c|}
\hline & \multicolumn{7}{|c|}{ Преобладающая группа микроорганизмов по данным культурального исследования (количество проб) } \\
\hline $\begin{array}{l}\text { Преобладающая } \\
\text { группа } \\
\text { микроорганизмов } \\
\text { по данным ПЦР-РВ }\end{array}$ & $\begin{array}{c}\text { Грамположительные } \\
\text { факультативные } \\
\text { анаэробы } \\
(n=15)\end{array}$ & $\begin{array}{c}\text { Грамотрицательные } \\
\text { факультативные } \\
\text { анаэробы } \\
(n=4)\end{array}$ & $\begin{array}{c}\text { Энтеробактерии / } \\
\text { энтерококки } \\
(n=23)\end{array}$ & $\begin{array}{c}\text { Облигатные } \\
\text { анаэробы } \\
(n=27)\end{array}$ & $\begin{array}{c}\text { Транзиторная } \\
\text { микрофлора } \\
(n=7)\end{array}$ & $\begin{array}{c}\text { Смешанная } \\
\text { микрофлора } \\
(n=10)\end{array}$ & $\begin{array}{l}\text { Микрофлора } \\
\text { отсутствовала }\end{array}$ \\
\hline $\begin{array}{l}\text { Грамположительные } \\
\text { факультативные } \\
\text { анаэробы }(n=15)\end{array}$ & 8 & 0 & 2 & 0 & 0 & 1 & 4 \\
\hline $\begin{array}{l}\text { Грамотрицательные } \\
\text { факультативные } \\
\text { анаэробы }(n=4)\end{array}$ & 0 & 0 & 0 & 0 & 0 & 1 & 2 \\
\hline $\begin{array}{l}\text { Энтеробактерии / } \\
\text { энтерококки }(n=23)\end{array}$ & 9 & 0 & 8 & 0 & 0 & 3 & 3 \\
\hline $\begin{array}{l}\text { Облигатные } \\
\text { анаэробы }(n=27)\end{array}$ & 11 & 1 & 4 & 4 & 1 & 4 & 2 \\
\hline $\begin{array}{l}\text { Транзиторная } \\
\text { микрофллора }(n=7)\end{array}$ & 5 & 0 & 0 & 0 & 1 & 0 & 1 \\
\hline $\begin{array}{l}\text { Смешанная } \\
\text { микрофлора }(n=10)\end{array}$ & 7 & 0 & 2 & 0 & 0 & 0 & 1 \\
\hline $\begin{array}{l}\text { Микрофлора } \\
\text { отсутствовала }\end{array}$ & 0 & 0 & 0 & 0 & 0 & 0 & 0 \\
\hline
\end{tabular}


выявленного культуральным методом, были обнаружены представители других групп бактерий. Преобладающая группа микроорганизмов в микробиоте эякулята по данным культурального исследования полностью соответствовала результатам ПЦР-РВ только в 24,4\% проб, в большинстве случаев получение дискордантных результатов было обусловлено невозможностью выявить при культуральном исследовании некультивируемые и трудно культивируемые группы облигатно анаэробных бактерий, которые обнаружили с помощью теста Андрофлор. Этиологическая значимость выявления определенных преобладающих групп микроорганизмов и их количеств в эякуляте требуют проведения дальнейшего исследования с учетом клинических данных и диагноза пациента.

\section{Литература}

1. Cornelia Gottschick, Zhi-Luo Deng, Marius Vital et al. The urinary microbiota of men and women and its changes in women during bacterial vaginosis and antibiotic treatment. Microbiome. 2017; 5 (99): 1-15.

2. Hou D, Zhou X, Zhong X, et al. Microbiota of the seminal fluid from healthy and infertile men. FertilSteril. 2013 Nov; 100(5): 1261-9.

3. Nelson DE, Dong Q, Van der Pol B, et al. Bacterial communities of the coronal sulcus and distal urethra of adolescent males. PLoS One. 2012; 7 (5): e36298.

4. Weng SL, Chiu CM, Lin FM, et al. Bacterial communities in semen from men of infertile couples: metagenomic sequencing reveals relationships of seminal microbiota to semen quality. PLoS One. 2014 Oct 23; 9 (10): e110152.

5. Domes T, Lo KC, Grober ED, et al. The incidence and effect of bacteriospermia and elevated seminal leukocytes on semen parameters. Fertil Steril. 2012 May; 97 (5): 1050-5.

6. Mändar R, Punab M, Korrovits P, et al. Seminal microbiome in men with and without prostatitis. Int J Urol. 2017 Mar; 24 (3): 211-6.

\section{References}

1. Cornelia Gottschick, Zhi-Luo Deng, Marius Vital et al. The urinary microbiota of men and women and its changes in women during bacterial vaginosis and antibiotic treatment. Microbiome. 2017; 5 (99): 1-15.

2. Hou D, Zhou X, Zhong X, et al. Microbiota of the seminal fluid from healthy and infertile men. FertilSteril. 2013 Nov; 100(5): 1261-9.

3. Nelson DE, Dong Q, Van der Pol B, et al. Bacterial communities of the coronal sulcus and distal urethra of adolescent males. PLoS One. 2012; 7 (5): e36298.

4. Weng SL, Chiu CM, Lin FM, et al. Bacterial communities in semen from men of infertile couples: metagenomic sequencing reveals relationships of seminal microbiota to semen quality. PLoS One. 2014 Oct 23; 9 (10): e110152.

5. Domes T, Lo KC, Grober ED, et al. The incidence and effect of bacteriospermia and elevated seminal leukocytes on semen parameters. Fertil Steril. 2012 May; 97 (5): 1050-5.

6. Mändar R, Punab M, Korrovits P, et al. Seminal microbiome in men with and without prostatitis. Int J Urol. 2017 Mar; 24 (3): 211-6.

7. Schuppe H-C, Pilatz A, Hossain H, et al. Urogenital Infection as a Risk Factor for Male Infertility. Deutsches Aerzteblatt Online. 2017. DOI: 10.3238/arztebl.2017.0339.

8. Божедомов В. А. Хронический простатит: новая парадигма лечения. Урология. 2016; (36): 78-90.

9. Инструкция по применению набора реагентов для исследования микрофлоры урогенитального тракта мужчин методом ПЦР в режиме реального времени Андрослор ${ }^{\circledR}$ Скрин (ООО НПО «ДНК-Технология»). Доступно по ссылке: http:www.dna-technology.ru/information/aboutamethod/.

10. Jungwirth A, Diemer T, Kopa Z, et al. EAU Guidelines on Male Infertility. 2017. Available from: https://www.researchgate.net/ publication/318239925_EAU_Guidelines_on_Male_Infertility_2017.

11. Aragón IM, Herrera-Imbroda B, Queipo-Ortuño MI, et al. The Urinary Tract Microbiome in Health and Disease. Eur Urol Focus. 2018 Jan; 4 (1): 128-38.

7. Schuppe H-C, Pilatz A, Hossain H, et al. Urogenital Infection as a Risk Factor for Male Infertility. Deutsches Aerzteblatt Online. 2017. DOI: 10.3238/arztebl.2017.0339.

8. Bozhedomov V. A. Hronicheskij prostatit: novaja paradigma lechenija. Urologija. 2016; (36): 78-90. Russian.

9. Instrukcija po primeneniju nabora reagentov dlja issledovanija mikroflory urogenital'nogo trakta muzhchin metodom PCR v rezhime real'nogo vremeni Androflor ${ }^{\oplus}$ Skrin (OOO NPO «DNKTehnologija»). Dostupno po ssylke: http:www.dna-technology.ru/ information/aboutamethod/. Russian.

10. Jungwirth A, Diemer T, Kopa Z, et al. EAU Guidelines on Male Infertility. 2017. Available from: https://www.researchgate.net/ publication/318239925_EAU_Guidelines_on_Male_Infertility_2017.

11. Aragón IM, Herrera-Imbroda B, Queipo-Ortuño MI, et al. The Urinary Tract Microbiome in Health and Disease. Eur Urol Focus. 2018 Jan; 4 (1): 128-38. 